\title{
Syntactic Analysis of Surah Qaf English Translation by Muhammad Taqiudin Al Hilali and Muhammad Muhsin Khan
}

\section{Analisis Sintaksis Terjemahan Surah Qaf dalam Bahasa Inggris oleh Muhammad Taqiudin Al Hilali dan Muhammad Muhsin Khan}

\author{
Nur Azizah, Yazid Basthomi*, Arif Subianto \\ Universitas Negeri Malang, Jl. Semarang No. 5 Malang, Jawa Timur, Indonesia \\ *Penulis korespondensi, Surel: yazid.basthomi,fs@um.ac.id
}

Paper received: 04-02-2021; revised: 16-02-2021; accepted: 28-02-2021

\begin{abstract}
The present research is an analytical study referring to the Quranic English translation. It specifically aims at analyzing the constituent structure of sentence types in Surah Qaf English translation by Muhammad Taqiudin Al Hilali and Muhammad Muhsin Khan. More particularly, this research sets out to identify the sentence types found in the translation and analyze them at the syntactic level. The data for this research are taken from al-quran.info.com, the trusted site for Qur'an online translation and commentary. The method used in this research is descriptive qualitative. Based on the analysis, the findings indicate that four sentence types (declarative, imperative, exclamatory, and interrogative) appear in the Surah Qaf English translation with different number of occurrences. This research is also conducted to find out the constituent structure of each sentence type. The results also show that each sentence type has a distinctive pattern of constituent and grammatical structure.
\end{abstract}

Keywords: Syntactic analysis, Sentence types, Quranic translation

\begin{abstract}
Abstrak
Penelitian ini merupakan sebuah studi analitik yang merujuk pada terjemahan Al Quran dalam Bahasa Inggris. Penelitian ini bertujuan untuk menganalisis struktur konstituen tipe-tipe kalimat yang ada pada terjemahan Surah Qaf dalam Bahasa Inggris oleh Muhammad Taqiudin Al Hilali dan Muhammad Muhsin Khan. Singkatnya, penelitian ini bertujuan untuk mendeskripsikan dan menganalisis secara sintaksis tipe-tipe kalimat yang ditemukan di hasil terjemahan tersebut. Data penelitian ini diambil dari al-quran.info.com, sebuah situs terpercaya khusus terjemahan dan tafsir online Al Quran. Metode yang digunakan adalah metode deskriptif kualitatif. Berdasarkan hasil penelitian, terdapat empat tipe kalimat dengan frekuensi yang berbeda-beda yang ditemukan dalam hasil terjemahan Surah Qaf, antara lain deklaratif, imperatif, seruan, dan interogatif. Hasil penelitian menunjukkan bahwa tiap tipe kalimat memiliki tipe konstituen dan struktur tata bahasa tersendiri.
\end{abstract}

Kata kunci: Analisis sintaksis, tipe kalimat, terjemahan Alquran

\section{Introduction}

Recently, research on the Holy Quran has become an inclination in the linguistics world. The Holy Quran is assessed as an interesting book to be analyzed since it is a Divine scripture in which the form is written like poem and prose. Even though it is seen as a literary work, it is proved as an inimitable masterpiece since nobody can beat its magnificence. Nevertheless, it is plausible to analyze the content and structure of the Holy Quran through a linguistic perspective at macro level or micro level. 
The Holy book is a guidance for Muslim across the globe which means understanding the content and meaning is necessary. Since it is written in Arabic language, while not all people have sufficient knowledge about it, translation to another language, including English, is needed for mankind. Translating the Holy Book is not an easy task because of the grammatical structure difference and some terms that lack an equivalence meaning from source language to target language. Not only that, the wrong translation might lead to the wrong interpretation which might change the true meaning. Therefore, uncovering the sentence structure of a translation contributes a significant importance in understanding the translation.

In linguistics, syntax is the study that examines how meaning and form are related in human language to help people understand language comprehensively (Adger, 2015). By understanding the rules of how the words should be put together in a sentence, we can avoid the grammatical errors which may cause misunderstanding. Aarts (2001) proposes syntactic notions that can make the analysis easier such as the word strings such as the order of words, the constituent function of a sentence, and the constituent form of a sentence. Those syntactic notions will help the researcher analyze the translation in this study. Furthermore, to make the analysis more practical, the data will be classified into the sentence type category.

Accordingly, a research conducted by Jaseem (2014) reveals the linguistic errors found in the micro-level such as morphology, grammar, and lexis. Some major sources of errors that have been found in his research are the first language interference, the ignorance of rule restrictions, and the attempt to present a factual accuracy of the interpretation of the Quran in linguistic style. In this view, this study fractionates the constituent structure of English translation of Surah Qaf, a chapter in the Holy Quran which remains special since the Prophet always recites it on Friday prayer.

To date, some studies have addressed the issues in syntactic analysis focusing on Quranic discourse. Huriyah (2014) investigates the syntactic structure to find the sentence pattern in Surah Al-Qadr English Translation by Muhammad Taqiuddin Al Hilali and Muhammad Muhsin Khan. While Huriyah found the syntactic pattern in her analysis, Dkhissi (2018) refers to some grammatical issues that illustrate the asymmetries in Quranic English translation including word order, tense shift, case asymmetry, Ellipsis, passive structure, selection restriction, and cross formation. Those issues are the indications that would change the implication of the original text of the Quran.

In addition, another study that focuses on the syntactic type is also conducted by Dukes, Atwell, and Sharaf (2010). The study concentrates on the choice of syntactic representation and highlights the key parts of annotation guidelines in Quranic Treebank. On the other hand, the research conducted by Putri (2017) investigates the syntactical pattern of sentences and phrases in the English translation of Surah Al-Qiyamah. Both of the research focused on the syntactic perspective. Another research on syntactic analysis is also conducted by Rahim and Jameel (2017) focusing on the analysis of the different translations of Surah Al-Fatiha. The research shows that the differences between Arabic and English grammar affect the translators in translating Surah Al-Fatiha. It also mentions the issues that the translators encountered in translating the Quran such as translating some quranic terms that are very rhetorical in their meaning and use.

Since this article also considers the effects of translation style to the meaning, the researcher picks up previous research as the background of study. The research in English 
Translation of the Quran is "Hilali-Khan Qur'an translation" by Musaji (2012). He points out that the translation of Quran done by Hilali-khan contains a lot of interpretations that are mistranslated that lead the readers to misunderstand the meaning of particular verses. This case is interested to be explored because Muhammad (2005) stated that the translation of Hilali-Khan is the most widely distributed version of the Quran in the English language throughout the English-speaking world. Accordingly, it is necessary to find out the syntactical patterns of Hilali-Khan's translation so that it can be understood well.

In line with the concern of this study, two research questions of this research are proposed, there are: 1) What types of sentence types are used in the translation of Surah Qaf English translation by Muhammad Muhsin Khan and Muhammad Taqiudin Al Hilali, 2) What are the constituent structure of sentence type found in Surah Qaf English translations by Muhammad Muhsin Khan and Muhammad Taqiudin Al Hilali.

According to Aarts (2001), there are four sentence types, they are; 1) declarative sentences, 2) imperative sentences, 3) exclamatory sentences, and 4) interrogative sentences. To identify the sentence types found in Surah Qaf translation, the researcher will analyze and match the types of sentence with its characteristics.

\section{Method}

In this study, the researcher uses a descriptive qualitative method. According to Glass and Hopkins (1984) as cited in Manystighosa (2019), the descriptive study consists of collecting the data on the description of events and then arranging, tabulating, describing, and explaining the collected data. This descriptive research suits the need to describe the linguistic aspect of this study, especially the syntactic structure in Quranic English translation. In order to provide rich answers to the research question in this study the researcher uses qualitative research as the approach. Dornyei (2007) stated that qualitative research concerned with subjective opinions, experiences, and feelings of individuals. Thus, the explicit goal of the research is to explore the participants' views of the situation being studied. Accordingly, the researcher analyzes the constituent structure of Surah Qaf English translation by Hillali-Khan using the perspectives and relevant theories. Therefore, the researcher finds out the sentence pattern in the translation.

The data source of this study is the English translation of Surah Qaf by Muhammad Taqiudin Al Hillali and Muhammad Muhsin Khan. The researcher retrieved the data through the internet al-quran.info.com, the trusted site for Qur'an online translation and commentary. The researcher took Surah Qaf as the selected data because the surah was revealed in Mecca in the early stage of Prophet Muhammad's preaching. It is to say that people tended to like and create literary works such as poems and prose in that era. On the other hand, this surah also remains important since the Prophet always used to recite it in the Friday prayer and on the Eid days. Given the above consideration, the researcher assumed that the wording and sentences of Surah Qaf are loaded with wonderful and meaningful messages behind it. Among other things, the translation also contains some syntactical features such as statements, commands, exclamations, or even questions that can be analyzed. Thus, it is in line with the research which focuses on uncovering the constituent structure in English translation.

The researcher took several steps in analyzing the data. First, after collecting the data, the researcher paraphrased the surah into sentence form. After that, the researcher deleted all of the translators' interpretation or additional information given by the translators. With that 
intention, the researcher only focused on analyzing the translation. Then, the sentences are classified according to their sentence types such as declarative, imperative, interrogative, and exclamatory to find the occurrence of each sentence type and calculated into a percentage. In the following steps, the researcher analyzed all the sentences found in the English translation of Surah Qaf by Hillali-Khan using labeled bracketing. In the final analysis, the researcher elaborated the sentence structure in order to determine the syntactic pattern inside it. Last but not least, the researcher drew the conclusion based on the findings discussed in this research.

\section{Finding and Discussion}

The chapter presents the findings of the analysis of syntactic patterns as the answer to the research question. In addition, this chapter also discusses the reason beneath each occurrence with a syntactic approach in accordance with the objective of Quranic English translation.

\subsection{Sentence Types}

There are four sentence types found in the English translation of Surah Qaf by Muhammad Taqiudin Al Hilali and Muhammad Muhsin Khan. The findings of sentence types are classified and the number of occurrences are shown in Table 1 below.

Table 1. Frequency of occurrence of the sentence types

\begin{tabular}{lcc}
\hline \multicolumn{1}{c}{ Sentence Types } & Number of Occurrence & Percentage \\
\hline Declarative & 14 & $41 \%$ \\
\hline Imperative & 8 & $23 \%$ \\
\hline Exclamatory & 7 & $21 \%$ \\
\hline Interrogative & 5 & $15 \%$ \\
\hline Total & 34 & $100 \%$ \\
\hline
\end{tabular}

Table 1 shows that there are 14 declarative sentences (41\%) which is the most highly used sentence types in Surah Qaf English translation, 8 imperatives sentences (23\%), 7 exclamatory sentences (21\%), and interrogative sentences $(15 \%)$ as the most slightly used sentence type in Surah Qaf translation.

Declarative, the predominant sentence that is highly used in the translation, is assumed to correlate with the theme of Surah Qaf. It declares the gloriousness of God reminded to death, the only sure thing of life, and rebirth, the sign of God's magnificence that must be believed. The declarative types also provide the enlightenment information that God's command is an important thing. Briefly speaking, it directs the slaves to be in the right path and phrases that hereafter is a truth that we should not deny for its coming. Apart from declarative sentences that highly used in the translation, imperative, exclamatory, and interrogative sentences have slight differences in the number of occurrences. Quran as the guide book for Moslem contains imperative sentences that are used to tell the readers what they should do or what they should avoid. This indeed seems to obey God's commands is peremptory. Also, it reminds the readers or God's slaves that His warning is real. On the other hand, exclamatory types, as listed in the table above, has a small number of occurrence. It implies that this sentence type is infrequently used in the translation. Interrogative, as the last sentence type found in the translation, only emerges for a small amount of the total data shows that questions rarely appear in the translation of Surah Qaf. 


\subsection{Grammatical Function and Form of Sentence Types}

As stated in the previous chapter, there are four sentence types found in the English translation of Surah Qaf including declarative, imperative, exclamatory, and interrogative sentences. Each sentence type has its syntactic pattern that will be discussed below.

1) Declarative Sentence

In declarative sentences, six sentence patterns are spotted as the way how to declare something or make a statement in Surah Qaf translation. Those patterns are presented and explained further below.

a. Interjection at the beginning of the sentence

The interjection words appear three times in declarative sentences. Here is the example of interjection words that occur in the beginning of the sentence:

Nay, but they have denied the truth, when it has come to them, so they are in a confused state (verse 5)

\begin{tabular}{|c|c|}
\hline Functional Level & Interjector + S/MC (Subject + Predicator + Object) \\
\hline Form Level & 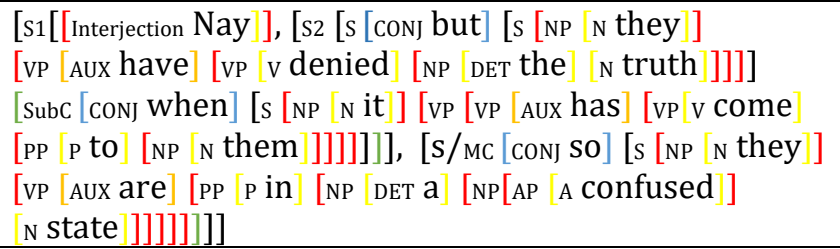 \\
\hline
\end{tabular}

From the example above, the word "nay" is considered as the interjection which always occurs at the beginning of the sentence and it is followed by the negative statement that contains negative expression. In this translation the word "nay" is translated from the Arabic word "ب̣". The word "ب̣" placed at the beginning of the sentence is considered as an unmarked structure in Arabic syntax which means it is pretty normal structure. Meanwhile in English, the placement of the word "nay" in the translation is considered as an uncommon structure.

Taking a look at the analysis, the sentence contains an interjection and complete sentence formed of subject, predicator, and object. The subject of the sentence is the pronoun "they" which refers to human beings or God's servant in specific. Then the predicator in the form of a verb phrase contains an auxiliary "have" and the verb "denied". The word "denied" shows the negative connotation which supports the interjection to declare something that is untrue. While the subject and the verb of the sentence are built in a simple form, the object is built by a simple noun phrase which is followed by two subordinate clauses. The NP is formed by the determinant "the" and a noun "truth" which become the main object of the sentence while two subordinate clauses function as the additional information of the main NP.

b. Adverbs

Verily, We it is Who give life and cause death; and to Us is the final return, on the Day when the earth shall be cleft, from off them, hastening forth (verse 43) 


\begin{tabular}{|c|c|}
\hline Function Level & $\begin{array}{l}\text { Sentence modifier +S/MC (Subject+Predicator+Subject } \\
\text { Complement) }\end{array}$ \\
\hline Form Level & 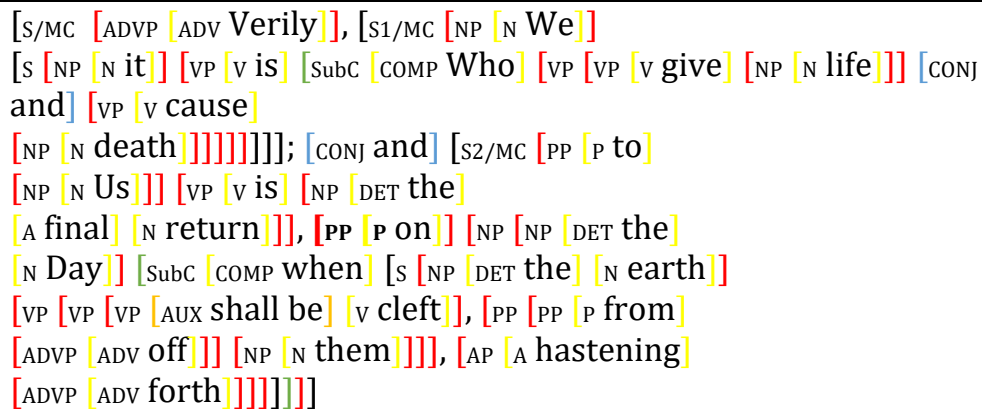 \\
\hline
\end{tabular}

Adverb is interpreted as a word that functions to answer the questions where, when, and how something happens. The sentence above gives an answer in a form of statement about the question where, when, and how we will return. In addition, the adverb "verily" shows that it modifies the whole sentence that expresses a certainty of the following sentence.

Engagingly, some syntactic phenomena such as double subject, parallel construction of a verb phrase, and unusual structure of subject. The double subject occurs at the following sentence after the main adverb that is a noun "we" and noun "it". The next is the parallel verb phrase in subordinate clause formed by a verb and a noun, the first verb phrase is "give life" and the second is "cause death". The last is the structure of the subject which is usually a noun phrase in general, in this sentence the subject of the second sentence is in a form of prepositional phrase which consists of preposition "to" and a noun "us".

c. That-clause as the direct object

In the declarative sentence, the researcher found that "that-clause" functions as the object of the verb. Below is the use of that-clause found in the declarative sentence of surah Qaf translation.

We know that which the earth takes of them and with Us is a Book preserved. (verse 4)

\begin{tabular}{|c|c|}
\hline Functional Level & Direct Object (that-clause) \\
\hline Form Level & 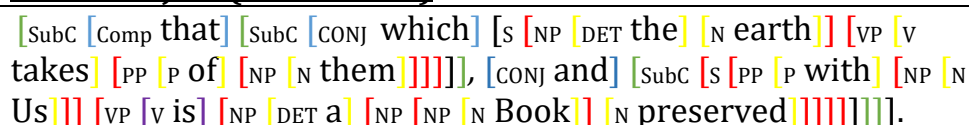 \\
\hline
\end{tabular}

The clause in the example above is known as a that-clause since it consists of the word "that" which functions as the complementizer between the verb phrase and the following clause. Here, that-clause functions as the direct object of the main sentence. The structure of the clause itself consists of two subordinate clauses connected by the word "and". Both of the subordinate clauses consist of subject and predicates, but both also have different constituent structure. The first subordinate clause uses a noun phrase "the earth" as the subject and while the second one uses prepositional phrase "to us" as the subject. In the predicator level, both are also formed by different structures. The first clause employs an action verb "takes" while the other clause engages a linking verb "is" which follows with a direct object.

d. Adjective clause as modifier

Some examples of adjective clause in declarative sentences functioned as a modifier are presented as follows: 
Verily, therein is indeed a reminder for him who has a heart or gives ear while he is heedful, (verse 37)

\begin{tabular}{|c|c|}
\hline Functional Level & $\begin{array}{l}\text { Disjunct adverbial }+ \text { Subject }+ \text { Predicator }+ \text { Subject } \\
\text { complement }\end{array}$ \\
\hline Form Level & 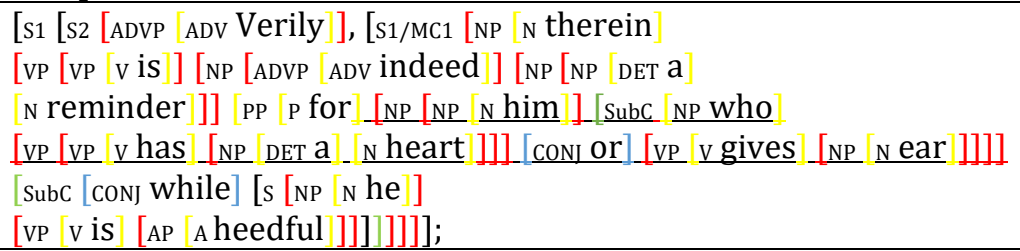 \\
\hline
\end{tabular}

This analysis will only focus on the structure of the adjective clause which functions as the modifier in the sentence. In the example above, the underlined adjective clause points back to the head of the noun phrase. In other words, it can be called the postmodifiers in a noun phrase. That is, it describes the detailed information of the noun which links to part of the main clause. The adjective clause functions as the modifier of the NP "him".

The modifier only completes the meaning of the noun it follows. As shown in the table, the adjective clause starts with the relative pronoun "who" marked as a noun phrase since it functions as the subject of the clause. Then the following two different structures of verb phrases which function as predicates are joined by the word "or". The first structure of the verb phrase uses the linking verb "has" which is followed by a noun phrase consisting of a determinant "a" and a noun "heart". Meanwhile the second verb phrase uses an action verb "gives" and a noun "ear".

e. The inversion of noun phrase and verb phrase

In English translation of Surah Qaf, there is a marked structure of a sentence which is the inversion of noun phrase and verb phrase. In English syntax the common structure of a sentence is always started with a noun phrase as the subject then followed by the verb phrase as the predicates. The example of the inversion is presented as follows:

Denied before them the people of Nooh, and the dwellers of Rass, and the Thamood, and $\mathrm{Ad}$, and Firaun, and the brethren of Lout, and the dwellers of the Wood, and the people of Tubba; (verse 12-14)

\begin{tabular}{|c|c|}
\hline Functional Level & Predicates + Subject \\
\hline Form Level & 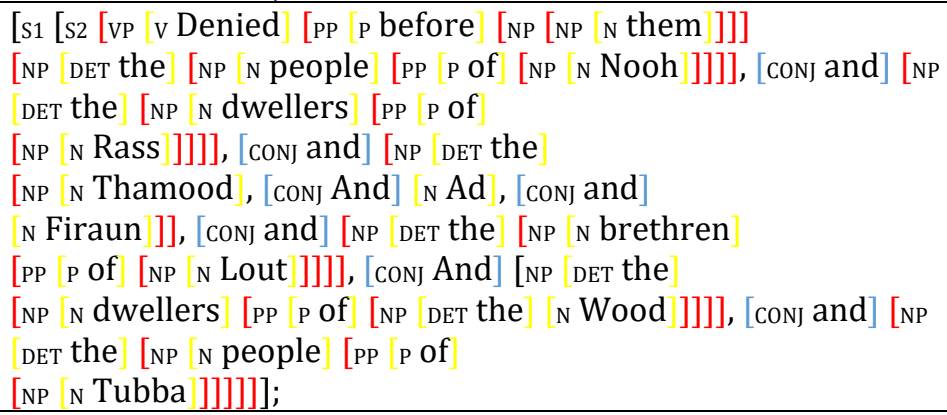 \\
\hline
\end{tabular}

As shown in the analysis, the sentence is started with the verb phrase as the predicates and followed by a very long noun phrase as the subject of the sentence. In this case, the translators seem to be following the Arabic syntax in translating the surah. It is proven by looking at the original text which starts with the verb " is "مقَومُ نوح". In Arabic syntax, it is common to start the sentence with a verb or verb phrase, 
meanwhile in English syntax the common structure of a sentence always starts with a noun or noun phrase. Accordingly, this translation is considered using the faithful translation method since it constrains the source language, Arabic, grammatical structure which shows the abnormality of the sentence structure in the target language, English (Newmark, 1988).

In addition, the subject of the sentence is considered as a heavy subject since it contains a long noun phrase. The noun phrase itself has three different structure and also different number of occurrences. The first structure of noun phrase repeated four times consists of determinant, noun, preposition, and noun as in "the people of Nooh". The second structure is arranged by a determinant "the" and three noun at once as "Thamood, Ad, Firaun" joined with the word "and". The last structure is decomposed by Det $+\mathrm{N}+\mathrm{P}+\mathrm{DET}+\mathrm{N}$ formula that occur only once as in "the dwellers of the wood".

f. Compound predicate

The verb phrase which occurs in coordinate pairs is called the compound predicate. In this case, the compound predicate occurs more than once which is joined with the conjunction "and". For convenience, the researcher provides the examples below:

And the earth! We have spread it out, and set thereon mountains standing firm, and have produced therein every kind of lovely growth, an insight and a Reminder for every slave turning to Allah. (verse 7)

\begin{tabular}{|c|c|}
\hline Functional Level & Object + Subject + Predicates \\
\hline Form Level & 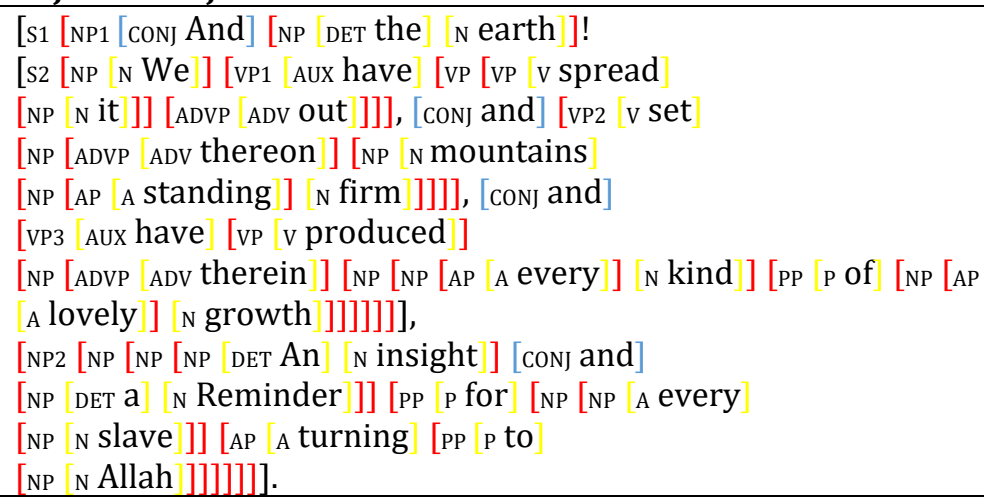 \\
\hline
\end{tabular}

In this subsection, the analysis of the sentence shows that there is a marked structure which occurs in the translation. The translators use the faithful translation method which attempts to reproduce the precise contextual meaning of the original within the constraints of the target language's grammatical structure so that it preserves the degree of grammatical and lexical 'abnormality' in the translation. For example, in the Arabic verse the object " mentioned first then the word "ه" is identified as the pronouns which refers to the same object mentioned previously. That structure is considered as an unmarked structure in the Arabic syntax. In translation above, the translators apply the Arabic structure in the English translation in which the object "and the earth!" (from the word الأرض) starts the sentence and the pronoun "it" (from the word $ه$ ) in "we have spread it out" is mentioned as the pronoun of the same object. However, the English translation structure becomes a marked structure since it is not common to mention the object at the beginning of the sentence. To make the sentence into a marked structure, the object should be placed after the verb as in "we have spread out the earth". 
Additionally, the predicates in the example above are considered as compound predicates made up with the same composition such as verb phrase and noun phrase. Even though each of the predicates has the same composition, the structure and word order are different. The predicates are divided into three parts marked with VP1, VP2, and VP3. The first and third predicate have the same composition of verb phrases which consists of an auxiliary "have" and followed by an action verb "spread" and "produced". Meanwhile the second predicate only has a verb "set" which follows a noun phrase.

2) Imperative Sentence

As the second sentence type which mostly occurs in Surah Qaf translation, two patterns are identified, namely zero subject and imperative moods.

a. Zero subject

The researcher found that there is no subject in almost all imperative sentences in English translation of Surah Qaf. Although there is no subject in the sentence, it is considered a grammatical sentence.

And listen on the Day when the caller will call from a near place, (verse 41)

\begin{tabular}{|c|c|}
\hline Functional Level & Zero subject + Predicator + Complement \\
\hline Form Level & 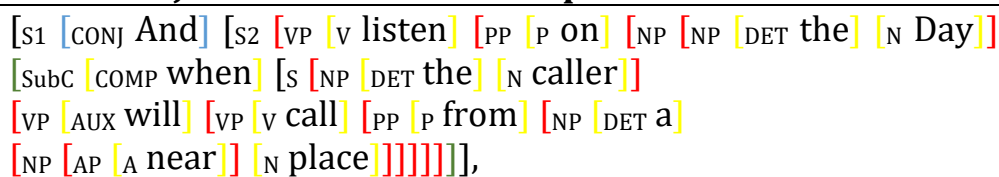 \\
\hline
\end{tabular}

As shown in the analysis, it starts with the verb phrase which means that the sentence has no subject stated obviously. In this view, the subject is called the understood subject in which the pronoun "you" is the subject of this sentence. In imperative sentences, it is very common to omit the subject in making a request or giving an order. The understood subject "you" can be proven via transformation from the deep structure to the surface structure of the sentence (Kadarisman, 2020). The use of tagged is also an evidence that the subject of the imperative sentence is always the pronoun "you". For example, the tag in the imperative sentence "listen on the day" should be "don't you?". As shown in the example, the verb in imperative sentences always be in the bare form which means that the subject should not be in the third-person "she, he or it". Furthermore, the pronoun also cannot be "I, they, or we", so that only the pronoun "you" can occur.

b. Imperative moods

Imperative mood is used as the verbal mood marker of imperative sentence type. The function of imperative moods is to express commands or requests and it is mostly formed using the present verb.

So bear with patience all that they say, and glorify the Praises of your Lord, (verse 39)

\begin{tabular}{|c|c|}
\hline Functional Level & $\begin{array}{l}\text { Zero Subject + Predicator + Adjunct + Direct Object } \\
\text { Zero Subject + Predicator + Object }\end{array}$ \\
\hline Form Level & 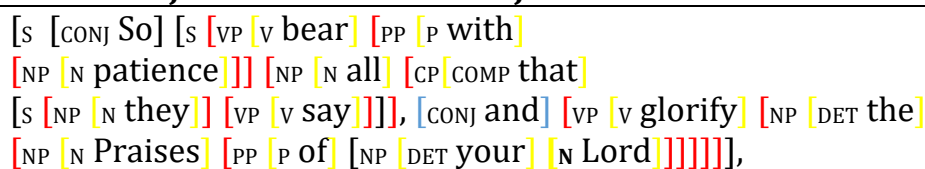 \\
\hline
\end{tabular}


The verb that initially starts the sentence is known as imperative moods. In this sentence, the verb has an important role in expressing a command. From the example above, there are two main sentences combined with the word "and" in which both of the sentences omit the subject. The first sentence has an imperative mood in the form of the verb "bear" and follows with the prepositional phrase as the object. Meanwhile the second sentence has the word "glorify" as the imperative mood and follows with a noun phrase as the object of the sentence.

3) Exclamatory Sentence

Only two patterns are found in this sentence type, they are: WH-phrase fronting and adjective as the sign of an exclamatory sentence.

a. WH-phrase fronting

And how many a generation We have destroyed before them, who were stronger in power than them, and they ran for a refuge in the land! (verse 36)

\begin{tabular}{|c|c|}
\hline Functional Level & Subject + Predicator + Object \\
\hline Form Level & 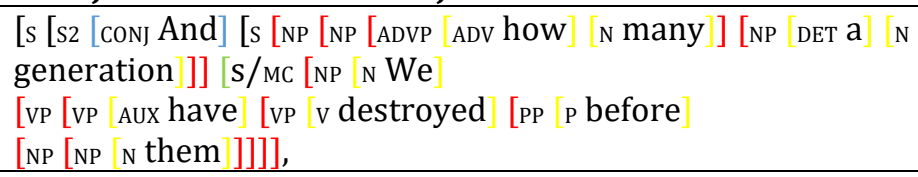 \\
\hline
\end{tabular}

The researcher found the word "how" as the part of the WH-phrase functioned as the initial phrase showing exclamation rather than asking questions. The researcher classifies the sentence above as the exclamatory sentence since there is no inversion between subject and predicate which happens in interrogative sentences. Also, the exclamation mark at the end of the sentence made the sentence clear that it is an exclamatory sentence.

b. Adjective as the sign of exclamatory sentence So the disbelievers say: "This is a strange thing!"

\begin{tabular}{|c|c|}
\hline Functional Level & Subject + Predicator + subject complement \\
\hline Form Level & $\begin{array}{l}{[\mathrm{NP} \text { N This }][\mathrm{vP} \text { AUX is }][\mathrm{NP} \text { DET a }} \\
\left.\left.\left.\left.\left[\underline{N}_{\mathrm{NP}}[\text { AP A strange }] \text { N thing }\right]\right]\right]\right]\right] !\end{array}$ \\
\hline
\end{tabular}

In general, the structure of an exclamatory sentence is formed by exclamatory phrases which are mentioned in the previous part. An adjective, however, also can be used to express an exclamation as mentioned in the example. The sentence has a subject "this", predicator "is", subject complement "a strange thing", and also exclamation mark "!" as a symbol of an exclamatory sentence. The adjective "strange" is considered as a strong expression that can be used as an indication that the sentence is an exclamation expression. It is also possible to transform the structure to the exclamation phrase which starts with the WH-word without changing the meaning. For example, from the sentence "this is a strange thing!" to "what a strange thing!". Both of the sentences have the same meaning but different structure.

4) Interrogative Sentence

An interrogative sentence is the most slightly appeared sentence type in Surah Qaf translation. Although interrogative sentences are still found, the sentences are not called for an answer but it is likely asked to make statements, in other words the researcher implies that the surah Qaf translation consists of rhetorical questions. The pattern of interrogative sentences found in Surah Qaf Translation is discussed below. 
Dornyei, Z. (2007). Research method in applied linguistics: Quantitative, qualitative and mixed method. Oxford: Oxford University Press

Huriyah. (2014). Syntactic analysis of the translation of the noble Quran by Muhammad Taqiuddin Al-Hilali and Muhammad Muhsin Khan. Ulumuna Jurnal Studi Keislaman, 18(2), 287-300. DOI: 10.20414/ujis.v18i2.855

Jaseem, Z.A. (2014). The noble Quran: A critical evaluation of Al-Hilali and Khan's translation. International Journal of English and Education, 3(2), 237-273.

Kadarisman, E. 2 July 2020. Personal Communication.

Manystighosa, A. (2019). Syntactic structure of Bahasa Isyarat Indonesia (BISINDO). Unpublished undergraduate thesis. Malang: Universitas Negeri Malang.

Newmark, P. (1988). A textbook of translation. New York: Prentice Hall.

Muhammad, K. (2005). Assessing English translation of the Quran. Middle East Quarterly, 12(2), 58-71.

Musaji, S. (2012). Hilali-Khan Qur'an translation. Retrieved from https://theamericanmuslim.org/tam.php?URL=http\%3A\%2F52Ftheamericanmuslim.org\%2Ftam.ph p\%Fthrough the_looking_glass_hilali_khan_quran_translation $\% 2 \mathrm{~F}$

Putri, A. (2017). A syntactic analysis on the English translation of Surah Al Qiyamah Using Tree Diagrams. LET: Linguistics, Literature and English Teaching Journal. 7(1). DOI: https://dx.doi.org/10.18592/let.v7i1.1510

Rahim, A.J. Jameel, N.I. (2017). A syntactic analysis of different translation of Al-Fatiha Sura: A contrastive comparative study. Journal of Applied Linguistics and Language Research. 4(6), 62-81.

The Qur'an. Online Translation and Commentary. (Online) (al-qur'an.info/\#trans) Accessed at 6th January 2020 